\title{
Sandro Mezzadra
}

\section{Kartografie anty- i alternowoczesności}

Dobro wspólne, któremu Michael Hardt i Toni Negri poświęcili swoją książkę, definiowane jest na skrzyżowaniu „tego, co naturalne” z „tym, co sztuczne”. Oznacza to, że jest ono nie do pomyślenia poza działaniem [praxis], w ramach którego „społeczna produkcja” przekształca „świat materialny”. Dobro wspólne jest zatem pojęciem o wysokiej historycznej gęstości: wieki dominacji i walki, cierpień doświadczanych w wyniku wyzysku pracy, a także praktyk oporu, określają to prawie geologiczne nawarstwienie się tego „świata (wciąż) do zyskania”. Badania Hardta i Negriego poświęcone poszukiwaniom nowych podstaw i nowego języka do wyrażenia polityki wyzwolenia dwudziestego pierwszego wieku, nie mogą pomijać - z powodu tych samych założeń, które je motywuja - genealogicznej podstawy, rekonstrukcji rozpoczynającej od potrzeb teraźniejszości, w której się znajdują. Już w Imperium jedną z najoryginalniejszych tez (i jedną z przyczyn sukcesu tej książki) było stwierdzenie, że "globalizacja” powinna być badana z historycznej perspektywy na różnych poziomach. Takie badanie powinno nie tylko łączyć ją ponownie z horyzontem wolnego rynku, który, zgodnie z marksowską lekcją wyciągniętą z teorii „systemów-światów”, charakteryzował produkcję kapitalistyczną od jej początków, ale także odkrywać na nowo rolę walk robotniczych i ruchów antykolonialnych sprzeciwiających się procesowi ujednolicania planety. W efekcie z pewnością nie uzyskujemy zmiany skali przemocy zrodzonej w procesie kapitalistycznej globalizacji, ale znacznie bogatsze przedstawienie każdego z tych procesów. Pozostaje ono w konflikcie i jest sprzeczne z przeważającą częścią, doprawdy dość mdłych, pism krytycznych na temat „neoliberalizmu" i pensée unique [dominującej ideologii].

Metoda genealogiczna została wykorzystana w Imperium w dopracowywanej przez lata, zwłaszcza w pracach Negriego, złożonej interpretacji nowoczesności. Zyskała ona także wyraz w jego studiach nad Kartezjuszem, Spinozą, Marksem oraz władzą konstytuującą.

Centralna dla tych badań idea, głosząca iż nowoczesność - od renesansu i pierwszych ujęć teorii suwerenności przez autorów takich, jak Bodin czy Hobbes - wiązała się z zerwaniem i gwałtownym starciem pomiędzy seriami historycznie zwycięskich tendencji, które umożliwiły nastanie czasu kapitału, własności i państwa, oraz z całością ruchów (w społecznym, politycznym i poznawczym czasie), które wyobraziły i realizowały politykę ,immanencji” opartą na radykalnej równości i wolności, ma swój początek w odkryciu kreatywnej mocy ludzkości. Dwie Europy, dwie nowoczesności to znamienny tytuł jednego z rozdziałów Imperium. Dziesięć lat później wiele spośród tych elementów interpretacyjnych zostało potwierdzonych, zwłaszcza w poszukiwaniach pojęcia dobra wspólnego [the common] poza homologią prawa publicznego i prywatnego, wyznaczając na nowo przestrzeń dla radykalnej krytyki własności, w koncepcji której znaleźć można „fundamenty każdej nowożytnej konstytucji politycznej”. 
Jednakże krytyczna genealogia nowoczesności została w Rzeczy-pospolitej wzbogacona o nowe wymiary, które okazują się cenne zarówno z punktu widzenia badań historycznych, jak i pod względem lepszego wyjaśnienia tego, co jest stawką współczesnych konfliktów społecznych.

Można powiedzieć, że, zgodnie z lekcją wyciągniętą z najbardziej przenikliwych studiów postkolonialnych, największą innowacją jest zdolność Hardta i Negriego do usytuowania całej kwestii nowoczesności w globalnych współrzędnych geograficznych. Bezpośrednim przykładem dwoistości nowoczesności (gdzie ta ostatnia, jak czytamy w Rzeczy-pospolitej, jest zawsze „relacją władzy: dominacji i oporu, suwerenności i walk o wyzwolenie”1) jest różnorodność „spotkań” określonych przez europejską ekspansję kolonialną w Ameryce, Azji i Afryce. Dalecy od przedstawiania wyzysku „wolnej” pracy zarobkowej jako czegoś „,normalnego” w kapitalistycznej produkcji, Hardt i Negri zastanawiają się nad konstytutywnym w określeniu globalnej nowoczesności charakterem niewolnictwa i innych form nie-wolnej pracy, strukturalnie związanych z mechanizmami „raso-

\section{Krytyczna genealogia nowoczesności została} w Rzeczy-pospolitej wzbogacona o nowe wymiary, które okazują się cenne zarówno z punktu widzenia badań historycznych, jak i pod względem lepszego wyjaśnienia tego, co jest stawką współczesnych konfliktów społecznych wej” dominacji. Polemizując z historycznymi rekonstrukcjami przedstawiającymi podporządkowane [subaltern] podmioty jako bierne i bezwolne, podkreślają oni zasadniczą rolę pełnioną przez heterogeniczne praktyki oporu tychże podmiotów w produkcji wspólnego świata, w którym wciąż żyjemy.

„Antynowoczesność" jest pojęciem używanym w Rzeczy-pospolitej do określania tych praktyk oporu, których protagonistami byli robotnicy i rdzenna ludność, kobiety i niewolnicy, najemni służący i rolnicy. Ale antynowoczesność, o której mówią Hardt i Negri, znajduje się całkowicie wewnątrz samej nowoczesności, jest od niej nieodłączna w tym sensie, że ucieleśniające ją siły działają wewnątrz cięcia i konstytuujących je spotkań. Te ostatnie nieustannie zmieniają i pogłębiają pojęcie wolności i równości, obracając je przeciwko „hierarchicznym, nowoczesnym relacjom władzy"2. Z pewnością mogą zaistnieć reakcyjne projekty antynowoczesne, których wspólna charakterystyka według autorów polega na usiłowaniu „zerwania zależności leżącej w samym sercu nowoczesności i uwolnienia tego, kto dominuje, od konieczności radzenia sobie z podporządkowanym"3. Tym, co liczy się jednak najbardziej, jest to, że nawet antynowoczesne siły wyrażające opozycję oraz pragnące wyzwolenia wyzyskiwanych i zdominowanych ryzykują utkwienie wewnątrz jedynie negatywnych koncepcji oporu, które mogą często stać się pożywką (odnosząc się do tezy Fanona, często wykorzystywanej w książce) dla nikczemnych poszukiwań mitologicznych źródeł $\mathrm{i}$ „przednowoczesnej" tradycji. W każdym wypadku to tutaj 
ostatecznie triumfuje nowoczesność. Mechanizmy władzy, a także własnościowa i hierarchiczna logika, które konstytuują jej strukturę, obszernie zademonstrowały możliwość życia z różnorodnymi „tradycjami” oraz zakorzenienia wewnątrz heterogenicznego środowiska kulturalnego.

Nacisk na to twarde jądro nowoczesności (możliwe do ustalenia w ciągłym panowaniu kapitału nad jego czasem i przestrzenia) jest tym, co odróżnia projekt Hardta i Negriego od prac wielu krytyków postkolonialnych, którzy rozwijają tezy o ,alternatywnych nowoczesnościach" na podstawie hermeneutyki uznającej różnorodność kulturowo zróżnicowanych interpretacji „nowoczesnego” tekstu. Rzecz-pospolita, dzięki kategorii „alternowoczesności”, proponuje znacznie bardziej radykalne rozpoznanie planu konwergencji sił „antynowoczesności”, gdzie możliwość przejścia od zwykłego oporu do tworzenia alternatywy jest wymierna: projekt polityczny celujący w instytucjonalizację dobra wspólnego, który może wyłonić się jedynie z praktycznej krytyki, nierozłącznej od egzystencji i reprodukcji kapitalizmu, logiki własności.

Kartografia antynowoczesności i alternowoczesności proponowana w tej książce jest bez wątpienia całkiem skuteczna. Jednak poza wniesionym przez ową kartografię wkładem w niekończącą się debatę nad nowoczesnością, ważne jest, by podkreślić sposób, w jaki precyzuje ona, w bardzo praktycznym sensie, znaczenie jednego z najczęściej powtarzanych w Rzeczy-pospolitej twierdzeń: obecnie najdonioślejszym terenem, o którego zajęcie walczą zarówno kapitalistyczna akumulacja, jak i formy oporu i walki, jest „produkcja podmiotowości”. Zinterpretowane poprzez pokrótce zrekonstruowane tutaj analizy, twierdzenie to czyni głównym problemem radykalną heterogeniczność podmiotów wyłaniającą się (a raczej produkowana) z licznych „spotkań”, które snują nowoczesną opowieść. I chociaż Hardt i Negri używają pojęcia spotkania, adaptując je ze studiów postkolonialnych, znają bardzo dobrze sposób, w jaki ten sam termin

\section{Obecnie najdonioślejszym terenem, o którego zajęcie walczą zarówno kapitalistyczna akumulacja, jak i formy oporu i walki, jest „produkcja podmiotowości”}

użyty został przez Marksa w pierwszym tomie Kapitatu podczas prób uporania się ze spotkaniem między kapitałem a pracą. Jest to także spotkanie wytwarzane dawniej i obecnie w wielości form, którym odpowiadają różne rodzaje „produkcji podmiotowości”. Co jakiś czas, w rozdziałach poświęconych „produkcji biopolitycznej” we współczesnym kapitalizmie, wydaje się, że obaj autorzy stracili z oczu radykalność tego problemu, podczas gdy jest to bardzo jasne w części poświęconej nowoczesności, gdzie różnorodność jest uznawana za „najważniejszy element politycznego projektu"'. 
Jednakże z drugiej strony, to świadomość tego problemu naprawdę usprawiedliwia znaczenie, jakie Hardt i Negri przypisują krytyce „polityki tożsamości”: często jeśli istnieje buntowniczy ruch przeciwko specyficznemu sposobowi upodmiotowienia u jego źródeł, jego krystalizacja w roszczeniach i kategoriach tożsamości reprodukuje granice i podziały, funkcjonalne względem ponownej artykulacji kontroli i społecznej hierarchii. Prowadzi to do klasycznego pytania o „politykę tożsamości" (rasa, etniczność, seksualność), ale także, w jesz- cze większym stopniu, na obszar pracy i przychodu, gdzie heterogeniczność pozycji i warunków, w których przeżywany jest wyzysk (na całym świecie) pozwala wzmocnić pewnego rodzaju korporacyjną politykę tożsamości. Ma to miejsce w przepaści pomiędzy tą heterogenicznością a wzrastającą rolą odgrywaną przez potencjał „dobra wspólnego” (wiedza, kooperacja, języki i afekty) we współczesnej produkcji kapitalistycznej, którą musimy przepracować, teoretycznie i praktycznie, po to, aby wyłonić „alternowoczesne” podmioty.

Przetożyt Mateusz Karolak

1 M.Hardt, A. Negri, Commonwealth, Cambridge MA 2009, s. 67.

2 Tamże, s. 117.

3 Tamże, s. 100.

4 Tamże, s. 111. 
SANDRO MEZZADRA - wykłada na wydziale Politica, Istituzioni e Storia na Uniwersytecie Bolońskim. Badacz i aktywista, jest częścią projektu Uninomade oraz autorem książek: Diritto di fuga. Migrazioni, cittadinanza, globalizzazione (Verona, 2006) oraz La condizione postcoloniale. Storia e politica nel presente globale (Verona, 2008).
Dane adresowe autora:

Dipartimento do Politica Instituzioni e Storia

Strada Maggiore, 4540125 Bologna

e-mail: sandro.mezzadra@unibo.it

Cytowanie:

S. Mezzadra, Kartografie anty-i alternowoczesności, „Praktyka Teoretyczna” nr 4/2011, http://www.praktykateoretyczna. pl/PT nr4 2011 Commonwealth/14.Mezzadra.pdf (dostęp dzień miesiąc rok) 